\title{
Ovarian function in nutritionally induced anoestrous cows: effect of exogenous gonadotrophin-releasing hormone in vivo and effect of insulin and insulin-like growth factor I in vitro
}

\author{
T. D. Hamilton, J. A. Vizcarra, R. P. Wettemann, B. E. Keefer and L. J. Spicer* \\ Department of Animal Science, Oklahoma State University, Stillwater 74078, OK, USA
}

\begin{abstract}
Ovarian function of nutritionally induced anoestrus cows was evaluated in vivo (Expt 1) and in vitro (Expt 2). In Expt 1, 32 nutritionally induced anoestrous beef cows were divided into four treatment groups receiving: (1) saline infusions at one pulse every $4 \mathrm{~h}$ for 13 days (control); (2) $2 \mu \mathrm{g} \mathrm{GnRH}$ at one pulse every $4 \mathrm{~h}(2 \mu \mathrm{g}$ infused in $1.8 \mathrm{ml}$ saline over $5 \mathrm{~min}$ ) for 13 days (GnRH-4); (3) $2 \mu \mathrm{g} \mathrm{GnRH}$ at one pulse every $1 \mathrm{~h}$ for 13 days (GnRH-1); and (4) continuous infusion of $2 \mu \mathrm{g} \mathrm{GnRH}$ (a total of $2 \mu \mathrm{g}$ in $34 \mathrm{ml} \mathrm{h}^{-1}$ ) for 13 days (GnRH-C). On the last day of treatment, cows were killed, ovaries were removed and follicular fluid samples $(n=149)$ were collected. The percentage of cows with luteal activity on day 13 was significantly different $(P<0.01)$ among treatments $(0,25,75$ and $25 \%$ for control, GnRH-4, GnRH-1 and GnRH-C cows, respectively). Owing to the large percentage of ovulatory cows in the GnRH-1 group $(n=6)$, anovulatory cows $(n=2)$ were removed from this treatment group for statistical analysis, as were cows with luteal tissue from the GnRH-4 $(n=2)$ and GnRH-C $(n=2)$ groups. The numbers of small $(1.0-4.9 \mathrm{~mm})$ and medium plus large $(\geq 5 \mathrm{~mm})$ follicles were not affected $(P>0.10)$ by treatment. However, GnRH-4 cows $(n=6)$ had greater $(P<0.05)$ concentrations of oestradiol in follicular fluid than did control $(n=8)$ but not GnRH-1 $(n=6)$ or GnRH-C $(n=6)$ cows. Concentrations of insulin-like growth factor I were greater $(P<0.05)$ in the follicular fluid of GnRH-1 cows than in all other treatment groups. Concentrations of androstenedione and progesterone in follicular fluid were not affected $(P>0.10)$ by treatment or follicle size. The binding activity of insulin-like growth factor binding proteins was not affected by $\mathrm{GnRH}$ treatment. However, the binding activity of insulin-like growth factor binding protein $2,29-32 \mathrm{kDa}$ and $22 \mathrm{kDa}$ insulin-like growth factor binding proteins were greater $(P<0.05)$ in small versus medium plus large follicles. In Expt 2, granulosa cells were collected from nutritionally anoestrous cows to determine whether ovarian cells from anoestrous cows have the capacity to respond to insulin-like growth factor I or insulin in vitro. Both insulin-like growth factor I (20 and $\left.200 \mathrm{ng} \mathrm{ml}^{-1}\right)$ and insulin $\left(10,100\right.$ and $\left.1000 \mathrm{ng} \mathrm{ml}^{-1}\right)$ increased $(P<0.05)$ granulosa cell proliferation and progesterone production. In conclusion, pulsatile infusion of $2 \mu \mathrm{g}$ GnRH (every 1 or $4 \mathrm{~h}$ ) for 13 days into nutritionally induced anoestrous cows results in increased intrafollicular oestradiol and insulin-like growth factor I concentrations and can stimulate ovulation without markedly affecting concentrations of androstenedione or progesterone, or the binding activity of insulin-like growth factor binding proteins, in follicular fluid. In addition, granulosa cells from nutritionally induced anoestrous cows have the capacity to respond to insulin-like growth factor I and insulin in vitro, indicating that the decrease in trophic factors observed with restricted feeding does not reduce the response of the ovary to insulin-like growth factor I and insulin.
\end{abstract}

\section{Introduction}

Severe nutrient restriction and loss of body energy reserves cause cessation of oestrous cycles in cattle (Richards et al., 1989a; Bishop and Wettemann, 1993). Restricted dietary

*Correspondence.

Received 30 October 1998. intake reduces the maximum diameter and persistence of dominant follicles (Murphy et al., 1991; Rhodes et al., 1995). Cows that become anoestrous owing to an inadequate plane of nutrition exhibit reduced concentrations of serum LH and fewer pulses of LH as they approach anoestrus (Imakawa et al., 1986; Richards et al., 1989a). In addition, plasma concentrations of insulin-like growth factor I (IGF-I) and insulin decrease as nutrient-restricted cows become 
anoestrous (Richards et al., 1989b, 1995). These decreases in IGF-I and insulin are thought to have direct effects on the ovary resulting in reduced follicular function (Spicer and Echternkamp, 1995). However, it is not known whether granulosa cells from nutritionally anoestrous cows are capable of responding to IGF-I or insulin. Although IGFbinding proteins (IGFBPs) are thought to regulate the bioactivity of IGF-I within the follicle (Spicer and Echternkamp, 1995), it is not known whether IGFBPs in follicular fluid are altered in nutrient-restricted cows. However, the pulsatile infusion of GnRH stimulates pulsatile LH secretion and resumption of luteal activity in cows that are nutritionally anoestrous (Bishop and Wettemann, 1993; Vizcarra et al., 1997). It is debatable whether luteal function induced by GnRH in nutritionally induced anoestrous cows is normal. The effect of pulsatile versus continuous GnRH infusion on ovarian activity and follicular fluid hormone concentrations in nutritionally induced anoestrous cows has not been evaluated. Moreover, whether IGF-I or insulin can stimulate granulosa cells isolated from nutritionally induced anoestrous cows has not been determined.

Experiments have been conducted to evaluate the effects of GnRH treatment on postpartum anoestrous cows (Riley et al., 1981; Walters et al., 1982; Spicer et al., 1986a,b). However, the results from these studies varied widely, possibly due to differences in the body energy reserves of cows or to the effect of the suckling stimulus. Nutritionally induced anoestrous cows provide a desirable model in which to compare ovarian response to exogenous $\mathrm{GnRH}$, infused either as pulses or through continuous infusion, since animal variability is reduced due to absence of the suckling stimulus and because cows are in a consistent physiological state during treatment. Therefore, the objectives of these present experiments were to determine: (1) the effects of pulsatile and continuous infusion of exogenous GnRH on the initiation of the oestrous cycle, the size and number of ovarian follicles, and the concentrations of oestradiol, androstenedione, progesterone, IGF-I and IGFBPs in the follicular fluid of nutritionally induced anoestrous cows; and (2) whether granulosa cells collected from nutritionally induced anoestrous cows have the capacity to respond to IGF-I or insulin in vitro.

\section{Materials and Methods}

\section{Experiment 1}

Animals and treatments. Thirty-two nonlactating, Hereford $\times$ Angus cows exhibiting normal oestrous cycles with body condition scores (BCS) of 5-6 (1 = emaciated and 9= obese; Wagner et al., 1988) were maintained in a dry lot and fed a restricted diet until they became anoestrous as described by Vizcarra et al. (1997). The diet was designed so that cows would lose approximately $1 \%$ of their initial body weight per week. Measurements of body weight and BCS were taken every 14 days. Blood samples were collected once per week via venepuncture in $10 \mathrm{ml}$ vacutainer tubes containing EDTA to prevent clotting. Blood samples were placed on ice and centrifuged ( $3000 \mathrm{~g}$ for $20 \mathrm{~min}$ ) within $4 \mathrm{~h}$ after collection.
Plasma was decanted and stored at $-20^{\circ} \mathrm{C}$ until progesterone was quantified. Cows were determined to be anoestrous when concentrations of progesterone in plasma were $<1 \mathrm{ng}$ $\mathrm{ml}^{-1}$ for 3 consecutive weeks. At anoestrus, all cows had an average $\mathrm{BCS}$ of $3.5 \pm 0.2$.

Cows were confined indoors in individual stalls within 3 weeks after the onset of anoestrus. Environmental factors were controlled during confinement at $21 \pm 4^{\circ} \mathrm{C}, 50 \pm 10 \%$ relative humidity and $14 \mathrm{~h}$ of light per day. Each cow was fed a diet of $5.5 \mathrm{~kg}$ prairie hay and $35 \mathrm{~g}$ mineral mix daily at $09: 00 \mathrm{~h}$ to maintain body weight and the nutritional anoestrous condition. A polyvinyl jugular cannula (inner diameter $1.68 \mathrm{~mm}$, outer diameter $2.39 \mathrm{~mm}$, Bolab, Lake Havasu City, AZ) was inserted into each external jugular vein for hormone infusion and collection of blood. Cannulae were inserted 2 days before initiation of treatment.

Cows were assigned randomly to one of four treatment groups receiving, for 13 days: (1) infusions (i.v.) of $1.8 \mathrm{ml}$ saline $\mathrm{h}^{-1}$ at one pulse every $4 \mathrm{~h}$ (control); (2) $2 \mu \mathrm{g} \mathrm{GnRH}$ in $1.8 \mathrm{ml}$ saline (Sigma Chemical Co., St Louis, MO) infused at one pulse every $4 \mathrm{~h}$ (GnRH-4); (3) $2 \mu \mathrm{g} \mathrm{GnRH}$ infused at one pulse every $1 \mathrm{~h}(\mathrm{GnRH}-1)$; and (4) continuous infusion of $2 \mu \mathrm{g} \mathrm{GnRH}$ in $34 \mathrm{ml} \mathrm{h}^{-1}$ (GnRH-C). The 13 day treatments began at $08: 00 \mathrm{~h}$ on day 0 and were continued until 08:00 h on day 13. All pulsatile infusions (control, GnRH-4, GnRH-1) were administered via a Harvard infusion pump (Model 931, Harvard Infusion-Withdrawal Pump, South Natick, MA) controlled by an automatic timer (Model CD-4, ChronTrol, Lindburg Ent., San Diego, CA). The pump-timer unit was calibrated to deliver the assigned pulse of saline or GnRH over a $5 \mathrm{~min}$ interval. The continuous infusion of GnRH (GnRH-C) was disbursed using a peristaltic pump that delivered $34 \mathrm{ml} \mathrm{h}^{-1}$. Heparin (1 USP ml-1) and penicillin (50 $\mathrm{U} \mathrm{ml}^{-1}$ ) were added to sterile saline to prevent clotting and bacterial contamination of cannulae during infusion. Season 1 included cows $(n=17)$ with treatments initiated between 1 October 1993 and 24 May 1994, with monthly ambient temperatures averaging between 4 and $14^{\circ} \mathrm{C}$. Season 2 included cows $(n=15)$ treated between 25 May and 30 August 1994, with monthly ambient temperatures averaging between 27 and $29^{\circ} \mathrm{C}$.

Blood samples $(10 \mathrm{ml})$ were collected daily from each animal from day 1 to day 12 of treatment in $10 \mathrm{ml}$ vacutainer tubes containing EDTA, processed as described above, and stored at $-20^{\circ} \mathrm{C}$ until IGF-I and progesterone concentrations were quantified by radioimmunoassay. In addition, both ovaries of each cow were evaluated using transrectal ultrasonography every 2 days during the treatment period to access formation of corpora lutea, as described by Vizcarra et al. (1997).

On day 13, cows were removed from treatment and taken to a local abattoir. After the animals were killed, ovaries were removed, placed on ice and transported to the laboratory. Follicles on each ovary were counted and measured using callipers and recorded as either small $(1.0-4.9 \mathrm{~mm})$ or medium plus large $(\geq 5 \mathrm{~mm})$. A sketch was drawn of each ovary and the location of each follicle, corpus luteum and corpus albicans was recorded. Follicular fluid was aspirated from each follicle using $1 \mathrm{ml}$ tuberculin syringes (Becton Dickinson and Co., Franklin Lakes, NJ) 
and placed into $12 \mathrm{~mm} \times 75 \mathrm{~mm}$ culture tubes. The follicular fluid samples from follicles on the same ovary measuring $\leq 4.9 \mathrm{~mm}$ were pooled in the same culture tube, while follicular fluid from each follicle measuring $\geq 5 \mathrm{~mm}$ was placed into individual culture tubes. Tubes were capped and placed on ice until all follicles had been aspirated. Samples were frozen at $-20^{\circ} \mathrm{C}$ until assayed for hormone concentrations.

Radioimmunoassays. Radioimmunoassays of IGF-I and progesterone were performed on both plasma and follicular fluid samples, whereas oestradiol and androstenedione concentrations were quantified by radioimmunoassay using only follicular fluid samples. Concentrations of IGF-I in plasma and follicular fluid were determined by radioimmunoassay after acid-ethanol extraction as described by Echternkamp et al. (1990). Intra- and interassay coefficients of variation were 13 and $16 \%$, respectively. Concentrations of oestradiol and progesterone in follicular fluid were quantified using a radioimmunoassay described by Spicer and Enright (1991). Intra- and interassay coefficients of variation were 10 and $25 \%$ for the oestradiol radioimmunoassay, and 19 and $19 \%$ for the progesterone radioimmunoassay, respectively. Concentrations of progesterone in plasma were determined in one assay using a solid-phase radioimmunoassay kit (Coat-ACount, Diagnostic Products Corp., Los Angles, CA) as described by Stewart $e t$ al. (1996). The intra-assay coefficient of variation was $10 \%$. Androstenedione concentrations in follicular fluid were determined using solid-phase radioimmunoassay kits (ICN Biomedicals, Costa Mesa, CA) as described by Stewart $e t$ al. (1996). Intra- and interassay coefficients of variation were 11 and $16 \%$, respectively.

Ligand blots. Plasma and follicular fluid IGFBPs were analysed by one-dimensional SDS-PAGE, as described by Echternkamp et al. (1994). Briefly, $4 \mu \mathrm{l}$ samples in $21 \mu \mathrm{l}$ denaturing buffer were heat denatured and then separated on a $12 \%$ polyacrylamide gel via electrophoresis. After separation, proteins in gels were transferred by electrophoresis to nitrocellulose paper, and ligand-blotted overnight with ${ }^{125}$ I-labelled IGF-I. After washing and then exposure of the nitrocellulose paper to X-ray film at $-70^{\circ} \mathrm{C}$ for $24 \mathrm{~h}$, band intensity on autoradiographs was determined using a PDI Model DNA 35 scanner and Quality One (version 2.4) software for quantification by scanning densitometry (PDI Inc., Huntington Station, NY).

Statistical analyses. Follicular fluid hormone data within each treatment were grouped on the basis of follicle size: small, $1.0-4.9 \mathrm{~mm}$ or medium plus large, $\geq 5 \mathrm{~mm}$. The main effects (treatment, follicle size, season) and their interaction were assessed by the general linear models (GLM) procedure of SAS (1988). Analysis of follicular fluid androstenedione, oestradiol and progesterone also included assay number in the model as a blocking factor (covariable). The main effects (treatment, follicle size, season) and interactions for IGFBP data were assessed by the GLM procedure of SAS (1988), with gel number included in the model as a blocking factor. Data are presented as least squares means. Specific differences among means were tested using Scheffe's method (Ott, 1977). Relationships among the various follicular fluid IGFBP activities and follicular fluid steroid concentrations were evaluated by regression and simple correlation analysis (Pearson correlation coefficients; SAS, 1988).

\section{Experiment 2}

Animals and cell culture. Ten nonlactating Hereford $x$ Angus cows were fed a restricted diet until they became anoestrous (as described in Expt 1) to determine and compare the effects of IGF-I and insulin on the proliferation and progesterone production of granulosa cells from nutritionally induced anoestrous cows. Cows were then killed in three groups of three or four cows each, ovaries were removed, and follicular fluid from small $(1.0-4.9 \mathrm{~mm})$ follicles was collected as described by Langhout $e$ t al. (1991). Follicular fluid from all three or four cows was pooled for each replication group. Granulosa cells were separated from the follicular fluid by centrifugation as described by Langhout et al. (1991). Cells were resuspended in serum-free medium, and the number of viable cells was determined using the Trypan blue exclusion method. The viability of the granulosa cells averaged $27 \%$.

Medium was a 1:1 (v/v) mixture of Dulbecco's modified Eagle's medium and Ham's F12 containing $0.12 \mathrm{mmol}$ gentamicin $1^{-1}$ and 38.5 mmol sodium bicarbonate $1^{-1}$. At the time of plating, $2 \times 10^{5}$ viable cells were added to Falcon 24well plates (Becton Dickinson and Co., Lincoln Park, NJ) containing $1 \mathrm{ml}$ medium. Cultures were kept at $38.5^{\circ} \mathrm{C}$ in a $5 \% \mathrm{CO}_{2}$ atmosphere. Cells were maintained in the presence of $10 \%$ fetal calf serum (FCS) for the first 2 days of culture to obtain optimal attachment. After the first 2 days of culture, cells were washed twice with $0.5 \mathrm{ml}$ serum-free medium and incubations were continued in serum-free medium, with or without added hormones. Medium was changed every day. Hormonal treatments were applied for 2 days (that is, from day 2 to day 4 of culture) and were either IGF-I (recombinant human IGF-I, R \& D Systems, Minneapolis, MN; 0,20 and 200 ng ml-1) or insulin (bovine, $25.7 \mathrm{U} \mathrm{mg}^{-1}$; Sigma Chemical Co.; $0,10,100$ or $1000 \mathrm{n} \mathrm{ml}^{-1}$ ). The doses of IGF-I and insulin were selected to represent the range of concentrations known to be effective in vitro (Spicer et al., 1993).

Determination of number of granulosa cells. The numbers of granulosa cells were determined at the termination of experiments using a Coulter counter (model $\mathrm{Zm}$, Coulter Electronics, Hialeah, FL) as described by Langhout et al. (1991). Briefly, cells were exposed to $0.5 \mathrm{ml}$ trypsin $(0.25 \%$ $(\mathrm{w} / \mathrm{v})$ in $\left.0.15 \mathrm{~mol} \mathrm{NaCl} \mathrm{l} \mathrm{l}^{-1}\right)$ for $20 \mathrm{~min}$ at $25^{\circ} \mathrm{C}$, and then scraped from each well, diluted in $0.15 \mathrm{~mol} \mathrm{NaCl}^{-1}$, and enumerated.

Progesterone radioimmunoassay. Concentrations of progesterone in culture medium collected on day 4 of culture were determined with a radioimmunoassay as described by Langhout $e t$ al. (1991) and Spicer and Enright (1991). Intraand interassay coefficients of variation were 12 and $11 \%$, respectively. 
Table 1. Numbers of nutritionally induced anoestrous cows with luteal-like activity during treatment with GnRH

\begin{tabular}{lcccccc}
\hline & & \multicolumn{5}{c}{ Number of cows } \\
\cline { 3 - 7 } Treatment $^{\mathrm{a}}$ & Total & Cyclic & $\begin{array}{c}\text { Day CL } \\
\text { first detected }\end{array}$ & $\begin{array}{c}\text { CL present } \\
\text { on day 13 }\end{array}$ & $\begin{array}{c}\text { With progesterone } \\
>1 \text { ng ml }^{-1 c}\end{array}$ & $\begin{array}{c}\text { Diameter of } \\
\text { CL (mm)d }\end{array}$ \\
\hline Control & 8 & 0 & - & 0 & 0 & - \\
GnRH-4 & 8 & 2 & 13 & 1 & 1 & 9.5 \\
GnRH-1 & 8 & 6 & $10 \pm 2$ & 6 & 1 & $11.0 \pm 0.6$ \\
GnRH-C & 8 & 2 & 7,9 & 2 & 0 & $11.5,16.0$ \\
\hline
\end{tabular}

${ }^{a}$ Treatments were as follows: control (saline), GnRH-4 (1 pulse per $4 \mathrm{~h}$ ), GnRH-1 (1 pulse ${ }^{-1}$ ), GnRH-C (continuous infusion).

'Day of treatment that a corpus luteum (CL) was first detected by ultrasonography.

'Number of cows with serum progesterone concentrations $>1 \mathrm{ng} \mathrm{ml} \mathrm{m}^{-1}$ for at least 3 days during the 13 day treatment.

${ }^{\mathrm{d} C L}$ diameter on day 13.

Statistical analysis. Experimental data are presented as the least squares means \pm SEM of measurements from triplicate culture wells from three replications. Main effects and interactions for dependent variables (that is, steroid production) were assessed using the GLM procedure of SAS (1988). Main effects were hormone treatment, experimental replicate, and their interaction. Each experimental replicate contained three wells (replicates) per treatment. When progesterone production was expressed as ng per $10^{5}$ cells per $24 \mathrm{~h}$, the number of cells at the termination of the experiment was used for this calculation. Specific differences in number of cells and progesterone production among treatments were determined using Scheffe's method (Ott, 1977).

\section{Results}

\section{Experiment 1}

Number of cows with luteal activity. A cow was considered to have luteal activity when a corpus luteum was present on the ovary upon visual examination after the animal was killed or if plasma progesterone was $>1 \mathrm{ng} \mathrm{ml}^{-1}$ for 3 days or more during treatment (Table 1). The percentages of cows with luteal activity were $0,25,75$, and $25 \%$ for cows in control, GnRH-4, GnRH-1 and GnRH-C groups, respectively (Table 1). The result for the GnRH-1 group was different $(P<0.01)$ from all other groups but the control, GnRH-4 and GnRH-C groups did not differ significantly from one another. The mean day of treatment on which the first corpus luteum was detected in GnRH-1 cows was day $10 \pm 2$ (Table 1). Owing to the large percentage of cows with luteal activity in the GnRH-1 group, all anovulatory cows $(n=2)$ were removed from this treatment group for statistical analysis, as were cows with luteal activity from the GnRH-4 $(n=2)$ and GnRH-C $(n=2)$ groups.

Number of follicles. Treatment had no effect $(P>0.10)$ on the number of small and medium plus large follicles, which were $34.9 \pm 9.5$ and $3.4 \pm 1.1$ per cow, respectively. The average diameter of follicles $\geq 5 \mathrm{~mm}$ and the average diameter of the largest follicle were not influenced $(P>0.10)$ by treatment and were $6.9 \pm 0.6 \mathrm{~mm}$ and $8.2 \pm 1.1 \mathrm{~mm}$, respectively.
Concentrations of oestradiol in follicular fluid. The GnRH treatment affected $(P<0.05)$ follicular fluid oestradiol concentrations such that GnRH-4 cows $(n=6)$ had greater $(P<0.05)$ oestradiol concentrations than control $(n=8)$ and GnRH-C $(n=6)$ cows but not GnRH-1 $(n=6)$ cows (Fig. 1a). However, there was no difference $(P>0.10)$ in oestradiol concentrations among control, GnRH-1 and GnRH-C cows. Oestradiol concentrations in follicular fluid also did not differ $(P>0.10)$ between small $\left(3.5 \pm 0.7 \mathrm{ng} \mathrm{ml}^{-1}\right)$ and medium plus large $\left(3.9 \pm 0.7 \mathrm{ng} \mathrm{ml}^{-1}\right)$ follicles. There was also an effect of season $(P<0.05)$ on the amount of oestradiol present in follicular fluid. The follicular fluid oestradiol concentrations of cows treated during the autumn-winterspring months (October-May) were $5.9 \pm 1.2 \mathrm{ng} \mathrm{ml}^{-1}$, and the follicular fluid oestradiol concentrations of cows treated during the summer months (June-August) were $2.2 \pm 0.8 \mathrm{ng}$ $\mathrm{ml}^{-1}$. No follicle size $\times$ season interaction or treatment $\times$ season interaction was apparent for oestradiol concentrations $(P>0.10)$.

Concentrations of progesterone and androstenedione in follicular fluid. There was no effect $(P>0.10)$ of $\mathrm{GnRH}$ treatment on concentrations of progesterone or androstenedione in follicular fluid (Fig. 1b). Similarly, there was no significant follicle size or treatment $\times$ size interaction for progesterone or androstenedione concentrations. Progesterone concentrations were $50.0 \pm 12.2$ and $74.1 \pm 13.7 \mathrm{ng} \mathrm{ml}^{-1}$ for small and medium plus large follicles, respectively, and this difference was not significant $(P>0.10)$. Similarly, follicle size did not affect $(P>0.10)$ androstenedione concentrations, which averaged $22.5 \pm 5.8$ and $21.8 \pm 6.5 \mathrm{ng} \mathrm{ml}^{-1}$ for small and medium plus large follicles, respectively. Follicular fluid androstenedione concentrations of cows treated during the autumn-winter-spring months were greater than those of cows treated during the summer months $(30.0 \pm 5.9$ versus $\left.23.4 \pm 9.5 \mathrm{ng} \mathrm{ml}^{-1} ; P<0.05\right)$. However, there was no effect $(P>0.10)$ of season on concentrations of progesterone in follicular fluid.

Ratio of oestradiol to progesterone concentrations in follicular fluid. The ratio of oestradiol to progesterone concentrations in follicular fluid was not affected $(P>0.10)$ by treatment and averaged $0.04,0.43,0.16$ and $0.07 \pm 0.13$ for control, GnRH-4, 

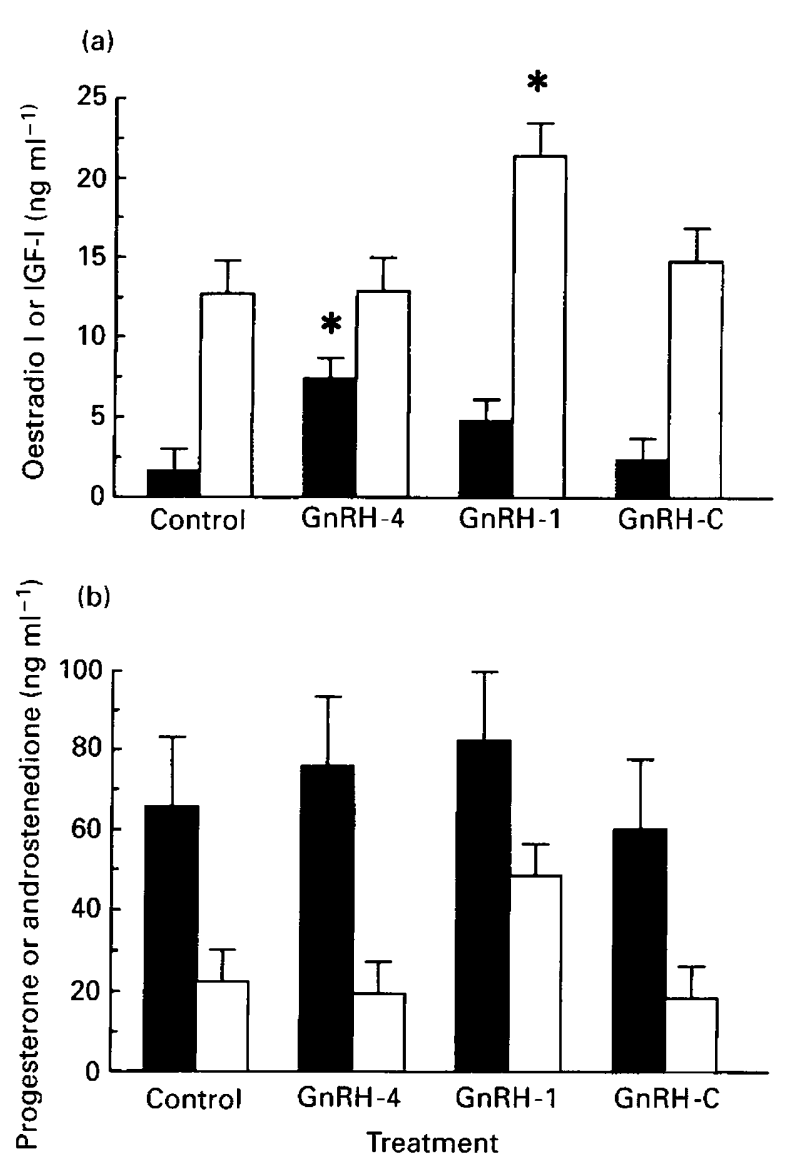

Fig. 1. Concentrations of (a) oestradiol ( $\square$ ) and IGF-I ( $\square$ ) and (b) progesterone ( $\square$ ) and androstenedione ( $\square$ ) in the follicular fluid of nutritionally induced anoestrous cows in Expt 1 after administration of $2.0 \mu \mathrm{g}$ exogenous GnRH given as one injection every $4 \mathrm{~h}$ (GnRH4), every $1 \mathrm{~h}(\mathrm{GnRH}-1)$, as a continuous infusion (GnRH-C) or controls. Data presented are combined from small $(1.0-4.9 \mathrm{~mm})$ and medium plus large ( $\geq 5 \mathrm{~mm}$ ) follicles because size and treatment $x$ size effects were not significant. *Mean differs from control value $(P<0.05) ; n=22-39$ samples per mean from $n=8$ anovulatory control cows, $n=6$ anovulatory GnRH- 4 cows, $n=6$ cyclic GnRH- 1 cows and $n=6$ anovulatory GnRH-C cows.

GnRH-1 and GnRH-C cows, respectively. Furthermore, neither follicle size nor season affected $(P>0.10)$ oestradiol:progesterone ratios. Oestrogen:progesterone ratios of all follicles in the analysis were $<1$ and, thus, all follicles were all deemed to be atretic.

Concentrations of insulin-like growth factor I in follicular fluid and plasma. Concentrations of follicular fluid IGF-I were not affected $(P>0.10)$ by either follicle size or treatment $\times$ follicle size. However, concentrations of IGF-I in follicular fluid were affected $(P<0.05)$ by treatment, such that concentrations of IGF-I in follicles from GnRH-1 cows were greater $(P<0.05)$ than those found in follicles of control cows (Fig. 1a). There was a tendency $(P<0.10)$ for season to affect follicular fluid IGF-I, such that follicular fluid IGF-I concentrations were greater during autumn-winter-spring $\left(17.5 \pm 1.7 \mathrm{ng} \mathrm{ml}^{-1}\right)$ than during summer $\left(13.4 \pm 1.3 \mathrm{ng} \mathrm{ml}^{-1}\right)$.

Plasma IGF-I concentrations on day 12 of treatment did

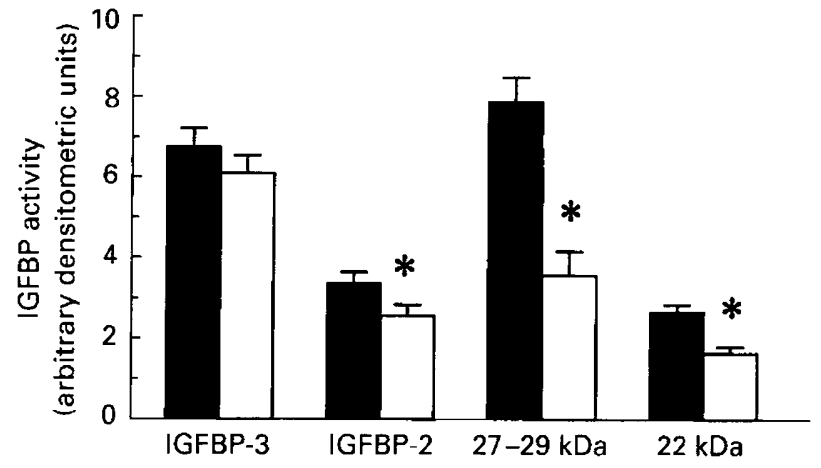

Fig. 2. Binding activity (in arbitrary units) of insulin-like growth factor-binding protein 3 (IGFBP-3), IGFBP-2, 29-32 kDa IGFBP, and a $22 \mathrm{kDa}$ IGFBP in the follicular fluid of small $(1.0-4.9 \mathrm{~mm}, \square)$ and medium plus large ( $\geq 5 \mathrm{~mm}, \square$ ) follicles of nutritionally induced anoestrous cows in Expt 1. Data presented are combined from all four treatment groups ( $n=26$ cows) because treatment and treatment $x$ size effects were not significant. ${ }^{*}$ Within follicle size, mean differs from small follicle mean $(P<0.05) ; n=41$ samples for small and $n=34$ samples for medium plus large follicle means.

not differ $(P>0.10)$ among control, GnRH-4, GnRH-1 and GnRH-C cows $\left(10.9,9.5,14.5\right.$ and $9.7 \pm 2.0 \mathrm{ng} \mathrm{ml}^{-1}$, respectively).

Concentrations of insulin-like growth factor binding proteins in follicular fluid. Ligand blotting revealed at least four forms of IGFBP activity in the follicular fluid of nutritionally anoestrous cows. These included a doublet at $40-44 \mathrm{kDa}$, singlets at 34 and $22 \mathrm{kDa}$, and a triplet between 29 and 32 $\mathrm{kDa}$. The doublet at $40-44 \mathrm{kDa}$ and the singlet at $34 \mathrm{kDa}$ were identified as IGFBP-3 and IGFBP-2, respectively. The identities of the $29-32 \mathrm{kDa}$ and the $22 \mathrm{kDa}$ IGFBPs were not determined in the present study; therefore, the triplet at 29-32 kDa was combined for analysis. The binding activity of IGFBP-3 was unaffected $(P>0.10)$ by treatment, follicle size (Fig. 2), season, or their interactions. There was no effect $(P>0.10)$ of treatment on the binding activity of IGFBP-2, the 29-32 kDa IGFBP or the 22kDa IGFBP; however, the binding activity of these three IGFBPs was affected $(P<0.05)$ by follicle size. Greater binding activity $(P<0.05)$ of these lower molecular mass IGFBPs was found in follicular fluid from small ( $\leq 4.9 \mathrm{~mm}$ ) follicles than in that from medium plus large ( $\geq 5 \mathrm{~mm}$ ) follicles (Fig. 2). In addition, cows treated during the summer months had increased binding activity of the lower molecular weight IGFBPs than did cows treated during the autumn-winter-spring months $(P<0.05)$. Binding activities (represented as arbitrary densitometric units \pm SEM) were $2.41 \pm 0.31,4.15 \pm 0.71$ and $1.83 \pm 0.20$ during the autumn-winter-spring months versus $3.52 \pm$ $0.21,7.29 \pm 0.47$ and $2.44 \pm 0.13$ during the summer months for IGFBP-2, the 29-32 kDa IGFBPs and the $22 \mathrm{kDa}$ IGFBP, respectively.

Correlation analysis revealed that concentrations of oestradiol in follicular fluid were negatively correlated with the 29-32 kDa IGFBP $(r=-0.24, P<0.05)$ and the $22 \mathrm{kDa}$ $\operatorname{IGFBP}(r=-0.20, P<0.10)$, but not IGFBP-2 $(r=-0.18, P>0.10)$ or IGFBP-3 $(r=-0.03, P>0.10)$. The concentrations of 
(a)

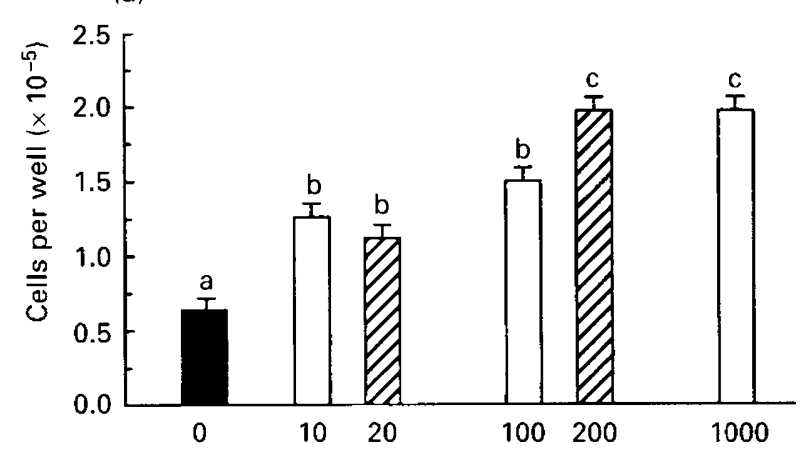

(b)

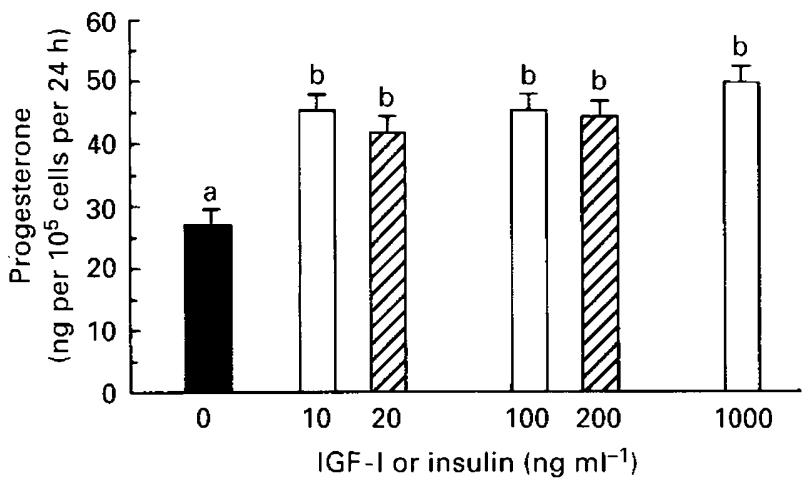

Fig. 3. Effects of insulin-like growth factor I (IGF-I, 叉) and insulin ( $\square$ ) on proliferation (a) and progesterone production (b) by granulosa cells collected from small follicles $(1-5 \mathrm{~mm})$ of nutritionally induced anoestrous cows (Expt 2). Granulosa cells were cultured for 2 days in the presence of $10 \%$ fetal calf serum and then treated in serum-free medium with the indicated doses of IGF-I or insulin for an additional 2 days. Values are means of three

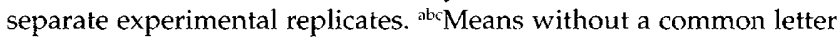
are significantly different $(P<0.05)$.

progesterone, androstenedione and IGF-I in follicular fluid were not significantly correlated with concentrations of any of the IGFBPs.

\section{Experiment 2}

Treatment with 10,100 and $1000 \mathrm{ng}$ insulin $\mathrm{ml}^{-1}$ increased $(P<0.01)$ the number of granulosa cells compared with controls (Fig. 3a). Similarly, 20 and $200 \mathrm{ng}$ IGF-I ml ${ }^{-1}$ increased $(P<0.01)$ the number of granulosa cells compared with controls (Fig. 3a). Stimulation of granulosa cell proliferation was greatest with $1000 \mathrm{ng}$ insulin $\mathrm{ml}^{-1}$ or $200 \mathrm{ng}$ IGF-I ml-1 $(P<0.01)$. In addition, $10 \mathrm{ng}$ insulin $\mathrm{ml}^{-1}$ and $20 \mathrm{ng}$ IGF-I ml-1 had similar stimulatory effects on number of granulosa cells (Fig. 3a).

Treatment with 10,100 and $1000 \mathrm{ng}$ insulin $\mathrm{ml}^{-1}$ increased $(P<0.01)$ progesterone production by granulosa cells compared with controls (Fig. 3b). Similarly, 20 and $200 \mathrm{ng}$ IGF-I ml-1 increased $(\mathrm{P}<0.01)$ progesterone production by granulosa cells compared with controls (Fig. 3b). All doses of insulin and IGF-I increased progesterone production by granulosa cells in a similar way (Fig. 3b).

\section{Discussion}

The results of the present study revealed that, after 13 days of treatment to nutritionally induced anoestrous cows, (1) pulsatile infusion of GnRH had no effect on the number of small and medium to large follicles or on concentrations of IGFBPs in follicular fluid; (2) pulsatile infusion of $\mathrm{GnRH}$ increased concentrations of oestradiol and IGF-I in ovarian follicular fluid; (3) follicle size did not affect concentrations of oestradiol, androstenedione, progesterone, IGF-I or IGFBP-3 in follicular fluid; (4) the season in which treatment was initiated had an effect on follicular fluid concentrations of oestradiol, androstenedione, IGF-I and IGFBP, but did not influence follicular fluid concentrations of progesterone; and (5) granulosa cells from nutritionally anoestrous cows had the capacity to respond to IGF-I and insulin under ideal culture conditions.

Treatment of nutritionally anoestrous cattle with exogenous GnRH did not affect the number of small or medium to large follicles present on the ovary regardless of whether treatments induced ovulation (that is, GnRH-1) or not (that is, GnRH-4). These results are in agreement with other data collected in postpartum anoestrous cattle in which numbers of follicles were not affected by $\mathrm{GnRH}$-induced changes in gonadotrophin secretion within 4 days after initiation of treatment (Spicer et al., 1986a). In GnRH-1 cows in the present study, ovulation (as assessed by first appearance of corpus luteum) occurred on average on day 10 of treatment. Therefore, follicle populations in GnRH- 1 cows were assessed on day 4 or 5 after ovulation, when a new follicular wave would have commenced (Stewart et al., 1996). The precise position of control, GnRH-4 and GnRH-C cows in terms of a follicular wave was uncertain.

The fact that GnRH treatment increased follicular fluid oestradiol concentrations was not surprising since the concentrations of oestradiol in plasma of cows were increased between days 2 and 12 of $\mathrm{GnRH}$ treatment (Vizcarra et al., 1997). In addition, oestradiol secretion was be induced with low-dose injections of GnRH in postpartum anovulatory cows (Walters et al, 1982; Spicer et al., 1986b). As follicles grow and become steroidogenically active, granulosa cells develop an increased aromatase activity, allowing for an increase in the conversion of androstenedione into oestradiol (Fortune, 1994). However, follicle size did not have an effect on oestradiol concentrations in follicular fluid in the present study. Why oestradiol concentrations in medium plus large follicles were low and not greater than concentrations in small follicles is not known, but is likely related to the fact that the average diameter of the largest follicle was $<10 \mathrm{~mm}$ in the present study whereas, in the other studies, the average diameter of the largest follicle was $10 \mathrm{~mm}$ (Spicer et al., 1986b,c; Spicer and Enright, 1991). Vizcarra et al. (1997) found that there was no increase in FSH concentrations when animals were infused with $2 \mu \mathrm{g}$ exogenous GnRH and, thus, FSH was assumed not to be a rate-limiting hormone for reproduction 
in nutritionally anoestrous cows. Therefore, the concentration of FSH present in nutritionally anoestrous cows may be adequate and other factors may be lacking to stimulate ovarian granulosa cells to produce oestradiol. Vizcarra et al. (1997) reported that LH concentrations were increased in GnRH-1 cows but not in GnRH-4 or GnRH-C cows during the 13 day treatment. Thus, a change in plasma LH concentrations cannot account for increased oestradiol concentrations in the follicular fluid of GnRH-4 cows. On the basis of the oestradiol:progesterone ratio (Ireland and Roche, 1983), all follicles in the present study were characterized as being atretic; thus, it is likely that many of the large follicles were atretic and possessed granulosa cells with decreased aromatase activity. Because androgens can be synthesized readily by LH-stimulated thecal tissues under in vitro conditions (Stewart et al., 1995) and androstenedione concentrations were within the range of normal healthy bovine follicles (Ireland and Roche, 1983; Stewart et al., 1996), it is unlikely that androgens synthesized by the theca interna was a limiting factor for follicular oestradiol production in the present study. Whether granulosa cells of nutritionally anoestrous cows have reduced aromatase activity will require further study, but the granulosa cells in this animal model may be immature due to nutrient depletion and are, therefore, unable to respond to the stimulation of FSH in vivo. However, results from Expt 2 demonstrated that granulosa cells from nutritionally anoestrous cows respond to both IGF-I and insulin in vitro. Because insulin and IGF-I enhance the response of granulosa cells to FSH (Spicer and Echternkamp, 1995) and both growth factors are reduced in nutritionally anoestrous cows (Richards et al., 1989b, 1991), the reduction in systemic and intraovarian IGF-I and insulin may be related to the reduced response of their follicles to GnRH treatment. The observation that intravenous pulsatile infusion of GnRH increased concentrations of oestradiol and IGF-I in follicular fluid and induced the onset of ovarian luteal activity in nutritionally induced anoestrous cows indicates that pulsatile secretion of $\mathrm{GnRH}$ is necessary for the stimulation of follicular growth and ovulation in cattle. Whether these GnRH treatments stimulated the development and maturation of new follicles or merely rescued follicles from atresia will require further study.

There was no effect of GnRH on the concentrations of progesterone in follicular fluid. This is in contrast to results in postpartum beef cows in which injections of $500 \mathrm{ng} \mathrm{GnRH}$ for 4 days decreased follicular fluid concentrations of progesterone in large ( $(28 \mathrm{~mm}$ ) follicles (Spicer et al., 1986b); in this same study, progesterone concentrations in small $(1.0-3.9 \mathrm{~mm})$ and medium $(4.0-7.9 \mathrm{~mm})$ follicles were not affected by GnRH treatment. Nutritional status does not appear to limit the synthesis of this steroid since the values reported in this study are in agreement with concentrations reported in normal cyclic cattle (Spicer and Enright, 1991; Spicer and Geisert, 1992). In support of this contention, granulosa cells isolated and cultured from nutritionally anoestrous cows in the present study were found to have the potential to respond to IGF-I and insulin in terms of progesterone production to an extent (that is, 1.6-1.8-fold) similar to that observed by Spicer et al. (1993). It is important to point out that this 4 day culture system optimizes the response of granulosa cells to hormones. Further studies are needed to determine whether freshly isolated granulosa cells from nutritionally induced anoestrous cows respond to hormones differently from those of contemporary cyclic control cows.

GnRH treatment did not affect follicular fluid concentrations of androstenedione in the present study; this is in agreement with the report of Spicer et al. (1986b) that $500 \mathrm{ng}$ of $\mathrm{GnRH}$ injected every $2 \mathrm{~h}$ in postpartum anoestrous cattle had no effect on follicular fluid androstenedione concentrations in small, medium or large follicles. The finding that follicular size did not have an effect on androstenedione concentrations is in agreement with the results of Echternkamp et al. (1994) and Spicer et al. (1986b) in normally cyclic beef cows and postpartum anoestrous beef cows, respectively.

Concentrations of IGF-I in the follicular fluid of the animals used in this study were very low compared with concentrations seen in normally cyclic cows and in cows subjected to short-term fasting (Spicer and Enright, 1991; Spicer and Geisert, 1992; Spicer et al., 1992). Serum concentrations of IGF-I were markedly lower in nutritionally induced anoestrous cows compared with contemporary cyclic control cows fed a maintenance diet (Richards et al., 1995). Whether intraovarian concentrations of IGF-I are less sensitive to nutritional deficiencies (such as those imposed in the present study) than are systemic concentrations of IGF-I remains to be determined. However, beef heifers fasted for 3 days have significantly reduced systemic IGF-I concentrations whereas follicular fluid IGF-I concentrations were unaltered (Spicer et al., 1992). Concentrations of IGF-I in follicular fluid were not different between the two sizes of follicle, but were greater in GnRH-1 cows than in control cows. How intraovarian changes in IGF-I concentrations regulate the $\mathrm{GnRH}$-induced changes in follicular function will require further elucidation. In well-fed postpartum anoestrous cows treated with pulsatile GnRH injections, changes in follicular function could not be ascribed to changes in intrafollicular IGF-I concentrations (Spicer et al., 1988).

The IGFBPs isolated in the present study were IGFBP-3, IGFBP-2, $29-32 \mathrm{kDa}$ IGFBP and a $22 \mathrm{kDa}$ IGFBP. The identities of the 29-32 kDa and the $22 \mathrm{kDa}$ IGFBPs were not determined; however, on the basis of other studies, the binding in the 29-32 kDa region corresponds to the immunoreactivity for IGFBP-5 in cattle (Stanko et al., 1994) and IGFBP-4 in sheep (Carr et al., 1994), while the binding activity in the $22 \mathrm{kDa}$ region may represent a deglycosylated form of IGFBP-4 since the molecular mass is similar to that of proteins identified as IGFBP-4 in sheep (Carr et al., 1994). The finding that follicle size had no effect on IGFBP-3 binding activity in follicular fluid is in agreement with results for normally cyclic cattle (Echternkamp et al., 1994; Stewart et al., 1996). The increased binding activities of IGFBP-2, the 29-32 $\mathrm{kDa}$ IGFBP and the $22 \mathrm{kDa}$ IGFBP in small follicles as compared with binding activity in medium plus large follicles is also in general agreement with results from previous studies in cyclic cattle (Echternkamp ct al., 1994; Stewart $e t$ al., 1996) in which IGFBP activity decreased as follicles developed and became oestrogen active. 
Consequently, IGFBP activity in cattle begins to increase as follicles begin to undergo atresia (Echternkamp et al., 1994). As stated earlier, most of the follicles in the nutritionally induced anoestrous cows of the present study were likely atretic because the oestradiol:progesterone ratios were $<1$ (Ireland and Roche, 1983). This hypothesis is further supported by the results of Stewart et al. (1996) in which binding activity of lower molecular mass IGFBPs in subordinate follicles were increased compared with the binding activity in dominant follicles of cyclic cattle. The relative binding activities of IGFBP-3, IGFBP-2 and the 22 $\mathrm{kDa}$ IGFBP in the present study are similar to the binding activities of those reported by Stewart et al. (1996). Whether the binding activity of the 29-32 kDa IGFBP is increased in nutritionally anoestrous cows compared with normally cyclic cows will require further study with contemporary controls. The negative correlations between oestradiol and low molecular mass IGFBPs observed in the present study were not as strong as previously reported for cyclic cattle (Echternkamp et al., 1994; Stewart et al., 1996) in which both oestrogen-active and oestrogen-inactive follicles were evaluated. One likely reason these correlations are low in the present study is that all follicles were oestrogen-inactive, and on the basis of previous reports (Echternkamp et al., 1994; Stewart et al., 1996), oestrogen-active follicles have predominantly low IGFBP activity. However, some large follicles of the present study did have very low IGFBP activity in spite of the fact that they were oestrogen-inactive (data not shown). Because the IGFBPs have been found potentially to regulate follicular development, by directly inhibiting IGF-I-induced androstenedione production by bovine thecal cells (Spicer et al., 1997), and oestradiol production by bovine granulosa cells (Spicer and Chamberlain, 1999), the reduction of oestradiol in the follicular fluid of nutritionally anoestrous cows could be a consequence of the increase in lower molecular mass IGFBPs (primarily the $29-32 \mathrm{kDa}$ binding protein). A greater proportion of the total IGFBP activity in large follicles was attributable to the 29-32 kDa IGFBPs in nutritionally anoestrous cows compared with normal cyclic cows, and may explain, in part, why there was no difference in concentration of oestradiol between the small and medium plus large follicles of nutritionally induced anoestrous cows.

The effect due to season on oestradiol, androstenedione and IGF-I were such that the concentrations of these hormones were greater when treatment was initiated during the cooler autumn-winter-spring months (October-May) than in the warmer summer months (June-August). However, the binding activity of IGFBP was greater when treatment was administered during the summer months compared with the autumn-winter-spring months. In contrast, McNatty et al. (1984) observed that follicular fluid oestradiol concentrations in cows were not affected by season. Although seasonal changes in ovarian function are not well defined in cattle, it appears that there are seasonal differences in bovine ovarian activity (Hauser, 1984) and that these differences are probably a result of seasonal differences in gonadotrophin secretion (Stumpf et al., 1988), intraovarian IGF-I concentrations, IGFBP-binding activity or other factors (Richards et al., 1995; present study).
Approved for publication by the director, Oklahoma Agricultural Experiment Station. This research was supported under Project $\mathrm{H}-2088$ and by the Cooperative State Research Service, USDA, under agreement number 92-37203-8038. The authors thank the National Hormone and Pituitary Program (University of Maryland School of Medicine, Baltimore) for supplying IGF-I antiserum, N. R. Mason (Lilly Research Laboratories) for the generous donation of oestradiol antiserum, the OSU Recombinant DNA/Protein Resource Facility for use of their scanning densitometer, and P. Cinnamon for her excellent secretarial assistance.

\section{References}

Bishop DK and Wettemann RP (1993) Pulsatile infusion of gonadotropinreleasing hormone initiates luteal activity in nutritionally anoestrous beef cows Journal of Animal Science 71 2714-2720

Carr JM, Grant PA, Francis GL, Owens JA, Wallace JC and Walton PE (1994) Isolation and characterization of ovine IGFBP-4: protein purification and cDNA sequences Journal of Molecular Endocrinology 13 219-236

Echtenkamp SE, Spicer LJ, Gregory KE, Canning SF and Hammond JM (1990) Concentrations of insulin-like growth factor I in blood and ovarian follicular fluid of cattle selected for twins Biology of Reproduction 43 8-14

Echternkamp SE, Howard HJ, Roberts AJ, Grizzle J and Wise T (1994) Relationships among concentrations of steroids, insulin-like growth factor I, and insulin-like growth factor binding proteins in ovarian follicular fluid of beef cattle Biology of Reproduction 51 971-981

Fortune JE (1994) Ovarian follicular growth and development in mammals Biology of Reproduction 50 225-232

Hauser ER (1984) Seasonal effects on female reproduction in the bovine (Bos taurus) Theriogenology 21 150-169

Imakawa K, Day ML, Zalesky DD, Garcia-Winder M, Kittok RJ and Kinder JE (1986) Influence of dietary induced weight changes on serum luteinizing hormone, estrogen and progesterone in the bovine female Biology of Reproduction $35377-384$

Ireland JJ and Roche JF (1983) Growth and differentiation of large antral follicles after spontaneous luteolysis in heifers: changes in concentration of hormones in follicular fluid and specific binding of gonadotropins to follicles Journal of Animal Science 57 157-167

Langhout DJ, Spicer LJ and Geisert RD (1991) Development of a culture system of bovine granulosa cells: effects of growth hormone, oestradiol and gonadotropins on cell proliferation, steroidogenesis and protein synthesis Journal of Animal Science 69 3321-3334

McNatty KP, Hudson N, Gibb M, Henderson KM, Lun S, Heath D and Montgomery GW (1984) Seasonal differences in ovarian activity in cows journal of Endocrinology 102 189-198

Murphy MG, Enright WJ, Crowe MA, McConnell K, Spicer LJ, Boland MP and Roche JF (1991) Effect of dietary intake on pattern of growth of dominant follicles during the oestrous cycle in beef heifers Journal of Reproduction and Fertility $\mathbf{9 2} 333-338$

Ott L (1977) Multiple comparisons. In An Introduction to Statistical Methods and Data Analysis pp 396-397 Duxbury Press, North Scituate, MA

Rhodes FM, Fitzpatrick LA, Entwistle KW and De'ath G (1995) Sequential changes in ovarian follicular dynamics in Bos indicus heifers before and after nutritional anoestrus fournal of Reproduction and Fertility 104 41-49

Richards MW, Wettemann RP and HM Schoenemann (1989a) Nutritional anoestrus in beef cows: body weight change, body condition, luteinizing hormone in serum and ovarian activity Journal of Animal Science 67 1520-1526

Richards MW, Wettemann RP and Schoenemann HM (1989b) Nutritional anoestrus in beef cows: concentrations of glucose and nonesterified fatty acids in plasma and insulin in serum Journal of Animal Science $672354-2362$

Richards MW, Wettemann RP, Spicer LJ and Morgan GL (1991) Nutritional anestrus in beef cows: effects of body condition and ovariectomy on serum luteinizing hormone and insulin-like growth factor I Biology of Reproduction 44961-966

Richards MW, Spicer LJ and Wettemann RP (1995) Influence of diet and ambient temperature on bovine serum insulin-like growth factor I and thyroxine: relationships with non-esterified fatty acids, glucose, insulin, luteinizing hormone and progesterone Animal Reproduction Science 37 267-279 
Riley GM, Peters AR and Lamming GE (1981) Induction of pulsatile LH release, FSH release and ovulation in post-partum acyclic beef cows by repeated small doses of GnRH Journal of Reproduction and Fertility 63 559-565

SAS (1988) SAS/STAT User's Guide 6th Edn, SAS Inst., Cary, NC

Spicer LJ and Chamberlain CS (1999) Insulin-like growth factor binding protein 3: its biological effect on bovine granulosa cells Domestic Animal Endocrinology 16 19-29

Spicer LJ and Echternkamp SE (1995) The ovarian insulin and insulin-like growth factor system with an emphasis on domestic animals Domestic Animal Endocrinology 12 223-245

Spicer LJ and Enright WJ (1991) Concentrations of insulin-like growth factor I and steroids in follicular fluid of preovulatory bovine ovarian follicles: effect of daily injections of a growth hormone-releasing factor analog and(or) thyrotropin-releasing hormone Journal of Animal Science 69 1133-1139

Spicer LJ and Geisert RD (1992) Concentrations of insulin-like growth factor I, oestradiol and progesterone in follicular fluid of ovarian follicles during early pregnancy in cattle Theriogenology 37 749-760

Spicer LJ, Convey EM, Tucker HA and Echternkamp SE (1986a) Effects of intermittent injections of LHRH on secretory patterns of LH and FSH and ovarian follicular growth during postpartum anovulation in suckled beef cows Journal of Animal Science 62 1317-1323

Spicer LJ, Convey EM, Tucker HA and Echternkamp SE (1986b) Effects of intermittent injections of LHRH on specific binding of ${ }^{125}$ [-labeled gonadotropins to granulosa and theca, and concentrations of steroids in serum and ovarian follicles during postpartum anovulation in suckled beef cows Journal of Animal Science 62 1324-1331

Spicer LJ, Leung K, Convey EM, Gunther J, Short RE and Tucker HA (1986c) Anovulation in postpartum suckled beef cows I. Associations among size and numbers of ovarian follicles, uterine involution, and hormones in serum and follicular fluid journal of Animal Science 62 734-741

Spicer LJ, Echternkamp SE, Canning SF and Hammond JM (1988) Relationship between concentrations of immunoreactive insulin-like growth factor I in follicular fluid and various biochemical markers of differentiation of bovine antral follicles Biology of Reproduction 39 573-580

Spicer LJ, Crowe MA, Prendiville DJ, Goulding D and Enright WJ (1992) Systemic but not intraovarian concentrations of insulin-like growth factor I are affected by short-term fasting Biology of Reproduction 46 920-925

Spicer LJ, Alpizar E and Echternkamp SE (1993) Effects of insulin, insulin-like growth factor I, and gonadotropins on bovine granulosa cell proliferation, progesterone production, oestradiol production, and(or) insulin-like growth factor production in vitro. Journal of Animal Science 71 1232-1241

Spicer LJ, Stewart RE, Alvarez P, Francisco CC and Keefer BE (1997) Insulinlike growth factor-binding protein 2 and 3 : their biological effects in bovine thecal cells Biology of Reproduction 56 1458-1465

Stanko RL, Cohick WS, Shaw DW, Harvey RW, Clemmons DR, Whitacre MD and Armstrong JD (1994) Effect of somatropin and/or equine chorionic gonadotropin on serum and follicular insulin-like growth factor 1 and insulin-like growth factor-binding proteins in cattle Biology of Reproduction $50290-300$

Stewart RE, Spicer LJ, Hamilton TD and Keefer BE (1995) Effects of insulinlike growth factor I and insulin on proliferation and on basal and luteinizing hormone-induced steroidogenesis of bovine thecal cells: involvement of glucose and receptors for insulin-like growth factor I and luteinizing hormone Journal of Animal Science 73 3719-3731

Stewart RE, Spicer LJ, Hamilton TD, Keefer BE, Dawson LJ, Morgan GL and Echternkamp SE (1996) Levels of insulin-like growth factor (IGF) binding proteins, luteinizing hormone and IGF-I receptors, and steroids in dominant follicles during the first follicular wave in cattle exhibiting regular estrous cycles Endocrinology 137 2842-2850

Stumpf TT, Day ML, Wolfe PL, Wolfe MW, Clutter AC, Kittok RJ and Kinder JE (1988) Feedback of $17 \beta$-oestradiol on secretion of luteinizing hormone during different seasons of the year Journal of Animal Science 66 $447-451$

Vizcarra JA, Wettemann RP, Braden TD, Turzillo AM and Nett TM (1997) Effect of gonodotropin-releasing hormone $(\mathrm{GnRH})$ pulse frequency on serum and pituitary concentrations of luteinizing hormone folliclestimulating hormone, GnRH receptors, and messenger ribonucleic acid for gonadotropin subunits in cows Endocrinology 138594-601

Wagner JJ, Lusby KS, Oltjen JW, Rakestraw J, Wettemann RP and Walters LE (1988) Carcass composition in mature Hereford cows: estimation and effect on daily metabolizable energy requirement during winter Joumal of Animal Science $66603-612$

Walters DL, Short RE, Convey EM, Staigmiller RB, Dunn TG and Kaltenbach CC (1982) Pituitary and ovarian function in postpartum beef cows III. Induction of estrus, ovulation and luteal function with intermittent small-dose injections of GnRH Biology of Reproduction 26 655-662 